\title{
Multi-Drug Resistance Bacteria: A Case Study in Western Peninsular Malaysia Freshwaters
}

\author{
Nor Azimah Mohd Zain ${ }^{1 *}$, Mohd Suardi Suhaimi ${ }^{2}$, Kam Kar Yern ${ }^{1}$, Mohd Farizal Ahmad \\ Kamaroddin ${ }^{1}$, Syahidatul Fazlina Samsul Rizal ${ }^{1}$, Syamimi Nadiah Baharudin ${ }^{1}$, Fatin Shahira Binti \\ Othman ${ }^{1}$, Nur Roslina Peer Muhammad Hussain ${ }^{1}$, Nurul Liyana Hassan ${ }^{1}$, Nurul Aqidah Salikan ${ }^{1}$, \\ Nur Hidayah Mohd Dzukhi ${ }^{1}$, \\ ${ }^{1}$ Department of Biosciences, Faculty of Science, Universiti Teknologi Malaysia 81310, Johor, Malaysia \\ ${ }^{2}$ School of Chemical Engineering, Faculty of Engineering, Universiti Teknologi Malaysia 81310, Johor, \\ Malaysia
}

Article history:

Submission August 2020

Revised January 2021

Accepted May 2021

*Corresponding author:

E-mail: azimah@fbb.utm.my

\begin{abstract}
The emergence of antibiotic resistant bacteria in the aquatic environment has led to an increase in waterborne health risks to an alarming extent. This study attempts to investigate the population of certain antibiotic resistant strains in Peninsular Malaysia. From the samples of 14 rivers from 7 different states, 203 isolates were successfully isolated. These were from rivers in Negeri Sembilan, Melaka, Selangor, Kuala Lumpur, Kedah, Kelantan and Terengganu with 35, 15, 37, 39, 24, 26 and 27 isolates, respectively. The isolates were tested for their susceptibility towards 6 broad spectrums of antibiotics which are gentamicin, ampicillin, rifampicin, chloramphenicol, tetracycline, and ciprofloxacin. Out of the 203 isolates, 117 isolates were identified to have more than 20\% MAR index value, with 47 of the isolates possess a minimum 50\% MAR index value. Based on MAR index value, 59\% of the isolates are high risk threats indicating a serious emergence of antibiotic resistant bacteria in the rivers in Peninsular Malaysia. Isolates with MAR index value of more than $50 \%$ were selected for $16 \mathrm{~S}$ rRNA gene sequencing for further identification. Based on 16s rRNA gene sequencing, the isolates are a mixture of pathogenic and commensals bacteria, implying that the environment, especially rivers, can be a reservoir for genetic jugglery.
\end{abstract}

Keywords: Antibiotic resistance bacteria, Broad spectrum antibiotics, Multiple antibiotic resistance index (MAR), Western peninsular Malaysia, 16s rRNA gene sequencing

\section{Introduction}

Antimicrobial resistance (AMR) refers to the multiplication of pathogenic microorganisms under the presence of antimicrobials. It was initially observed as an ordinary medical problem in hospital-acquired infections, particularly in critically ill and severely immunocompromised patients [1]. Today, AMR has become one of the recognized threats to the human population along with other common bacterial infections that are difficult to treat [2].

Approximately 700,000 people died each year from antimicrobial resistance bacterial infections
[3]. In Malaysia, the Malaysian Action Plan on Antimicrobial Resistance (MyAP-AMR) has been proposed to tackle a steady increase in antibiotic resistance, especially in common organisms. Global consumption of antibiotics by humans has risen by $40 \%$ in the first ten years of the 21st century. The BRIC nations (Brazil, Russia, India, China) contributed to three quarters of this growth [3]. Meanwhile, the use of veterinary pharmaceuticals has become vital to the animal food industry. As a perspective, there are approximately 34 million cattle (2015) and 9 billion chickens (2014) in 
the United States alone [4].

The emergence of human and animal antimicrobial resistant pathogens is a result of antimicrobial exploitation in humans and livestock [5]. The World Health Organization (WHO) proposed the elimination of antibiotics for growth promotion in agriculture that were also used in human medication. The European Union (EU) has also initiated several actions, including the removal of all antimicrobials used as a growth promoter in the livestock industry (Regulation EC 1831/2003) [6]. Many major livestock-producing countries have established their own national surveillance systems to ensure the use of antimicrobials in livestock and veterinary medicine is in control and monitor the antimicrobial resistance emergence. United States is one of such countries with the establishment of the National Antimicrobial Resistance Monitoring System for Enteric Bacteria (NARMS) in 1996 [7].

Antibiotics accumulation in the environment is from municipal and agricultural sources, including faeces, improperly disposed prescriptions, medical waste, discharge from wastewater treatment facilities, leakage from septic systems, and agricultural waste [8, 9]. Inefficient antibiotics degradation in the environment could result in the development and growth of antibiotic resistant microbial populations [10,11]. This condition could be worsened by the cyclic manure application on the same location that exposes the soil microbes to antibiotic residues and antibiotic resistant bacteria. Both antibiotic residues and antibiotic resistant bacteria could propagate in the environment by surface runoff or leached through soil and reach nearby rivers or lakes [8, 9].

Recent report by O'niell et al. [9] concluded that resistance might also propagate from its sources via water. Animal manure may contain antimicrobial compounds from on-farm livestock management. Antimicrobials in manure and biosolids may enhance the selection of resistant bacteria in the aquatic environment through diffuse pollution pathways [12].

In Malaysia, intensive agriculture, industrial activities, domestic wastewater and urban runoff have caused an impact on water pollution in the freshwater environment. The contamination in the freshwater environment could serve as a hotspot for the development of antibiotic resistance. Alhaj et al. [13] have conducted their study in Malaysia by studying the prevalence antibiotic resistance among Escherichia coli from different sources. Their study concluded that from 70 isolates of $E$. coli isolated from clinical, marine, river, food and animal farming sources, many of it (61.2\%) showed resistance towards 10 antibiotics tested. Their study also reflects the water quality and environmental contamination by antibiotics residues and antibiotic resistance bacteria (ARB) in Malaysia. Besides that, a study by Kathleen et al. [14] concluded that the bacterial isolates' multiple antibiotic resistant (MAR) index ranged between 0 and 0.63 in the aquaculture site in the eastern peninsular of Malaysia.

Therefore, this study aimed to investigate the emergence of AMR in Peninsular Malaysia by examining water samples from several rivers in Peninsular Malaysia. Samples were taken from rivers of 7 neighbouring states; Negeri Sembilan, Melaka, Kuala Lumpur, Selangor, Kedah, Terengganu and Kelantan. These rivers were chosen for sampling due to their proximity to densely populated settlements. Selangor ranked as the most populated state with a population of 5.46 million, followed by Kedah at 1.95 million, Kuala Lumpur at 1.67 million, Kelantan at 1.54 million, Terengganu at 1.04 million, Negeri Sembilan and Melaka at a population of 1.02 and 0.82 million, respectively [15]. The isolated bacteria were tested for physiological and biochemical characteristics, in addition to their susceptibility to antibiotics. Finally, the identification of the ARB was performed using 16s rRNA gene. Through this study, the freshwaters were evaluated for their implication of antibacterial resistance organism from river water to the public health and food security, which could contribute to more data on ARBs in the freshwater environment and overcoming the limitation on existing literature. This study could serve as preliminary data and provide potential clues for ARBs and ARGs contamination control.

\section{Material and Methods \\ Sample collection and bacterial isolation}

Two rivers from each seven neighbouring states in Peninsular Malaysia were chosen as sampling sites. These rivers were selected based on their locations near the aquaculture farm and residential area. The details of the sampling areas are tabulated in Table 1, in which samples were collected from Point A (upstream) and Point B (downstream). An amount of $500 \mathrm{ml}$ of water sample was collected in sterile glass bottles from the 
Table 1. Tables are numbered with Roman numerals and even at the beginning of a sentence

\begin{tabular}{|c|c|c|c|}
\hline States & Coordinate & Rivers & Number of isolates \\
\hline \multirow[t]{4}{*}{ Negeri Sembilan } & Point A: 2.720111, 102.022564 & Linggi & 7 \\
\hline & Point B: 2.657238, 101.994087 & & 12 \\
\hline & Point A 2.825212, 102.331082 & Jempol & 10 \\
\hline & Point B: 2.851562, 102.302156 & & 6 \\
\hline \multirow[t]{4}{*}{ Melaka } & Point A: 2.194627, 102.248791 & Melaka River & 5 \\
\hline & Point B: 2.202485, 102.251030 & & 3 \\
\hline & Point A: 2.340697, 102.060471 & Tuang river & 4 \\
\hline & Point B: 2.338305, 102.060361 & & 3 \\
\hline \multirow[t]{4}{*}{ Selangor } & Point A: 3.031978, 101.768573 & Langat & 9 \\
\hline & Point B: 2.896472, 101.72885 & & 8 \\
\hline & Point A: 3.221031, 101.590368 & Chemubong & 10 \\
\hline & Point B: 3.221058, 101.583678 & & 10 \\
\hline \multirow[t]{4}{*}{ Kuala Lumpur } & Point A: 3.170147, 101.695182 & Gombak & 9 \\
\hline & Point B: 3.170836, 101.686803 & & 8 \\
\hline & Point A: 3.178345, 101.682919 & Batu & 6 \\
\hline & Point B: 3.197522, 101.678123 & & 18 \\
\hline \multirow[t]{4}{*}{ Kedah } & Point A: 5.564073, 100.428082 & Kuala Muda & 6 \\
\hline & Point B: 5.582418, 100.374749 & & 9 \\
\hline & Point A: 5.634242,100.504987 & Sungai Petani & 7 \\
\hline & Point B: 5.639848, 100.475997 & & 5 \\
\hline \multirow[t]{4}{*}{ Kelantan } & Point A: 4.870728, 102.438744 & Lebir & 4 \\
\hline & Point B: 4.932378, 102.418298 & & 8 \\
\hline & Point A: 5.530988, 102.195158 & Kelantan & 8 \\
\hline & Point B: 5.612043, 102.144881 & & 7 \\
\hline \multirow[t]{4}{*}{ Terengganu } & Point A: 5.280724, 103.141581 & Ibai & 4 \\
\hline & Point B: 5.278680, 103.168602 & & 9 \\
\hline & Point A: 5.279265, 103.084646 & Terengganu & 6 \\
\hline & Point B: 5.328204, 103.125040 & & 5 \\
\hline
\end{tabular}

surface water of each river. The samples were then stored at a temperature of $4^{\circ} \mathrm{C}$ before being transferred to cold room until further analysis. Isolation of bacterial strains from each sample was performed using serial dilution and spread plate on nutrient agar. All the plates were incubated at $37^{\circ} \mathrm{C}$ for 24 hours. The single colonies of different morphology from the spread plates were streaked on nutrient agar for subcultures to obtain the pure colonies of the bacterial isolates.

\section{Antimicrobial susceptibility test}

Mueller-Hinton agar (MHA) was used in this study to grow the bacteria from the samples. This study used six different antibiotics: ampicillin, ciprofloxacin, chloramphenicol, gentamycin, tetracycline, and rifampicin. The concentration of antibiotics was set at $10 \mu \mathrm{g} / \mathrm{ml}$ and $30 \mu \mathrm{g} / \mathrm{ml}$. The antibiotic discs were prepared using Whatman filter paper no. 1 with a diameter of approximately 6 $\mathrm{mm}$. The colonies of the pure culture were trans- ferred into $5 \mathrm{ml}$ of nutrient broth medium. The broth culture was then incubated at $37^{\circ} \mathrm{C}$ until it achieves or exceeds the turbidity of 0.5 MacFarland standard after 2 to 6 hours of incubation. The antibiotics were applied to the sterilized discs the discs were dispensed onto the surface of the inoculated agar plate. The antimicrobial susceptibility test for each isolate was carried out in duplicate. The plates were incubated at $37^{\circ} \mathrm{C}$ for 24 hours. After 16 to 18 hours of incubation, the diameters of the zones of complete inhibition were measured. The inhibition zones are interpreted by referring to the Zone Diameter Interpretative Standards and equivalent Minimum Inhibitory Concentration Breakpoints [16].

\section{Determination of MAR index value}

The isolates' Multiple Index Resistance or MAR index value was determined by using the following equation [17].

$$
\text { MAR index value }=\frac{a}{b} \times 100
$$


Note:

a : Number of resistant antibiotics

b: Total number of the tested antibiotics

\section{Bacterial identification}

The bacterial isolates' DNA was extracted using the heat shock method, also known as the boiling-centrifugation method [14]. Two millilitres of the overnight bacterial cultures were centrifuged at 10,000 rpm for five minutes and the supernatant was discarded. Then, another two millilitres of the bacterial cultures were added to the same microcentrifuge tube and centrifuged at $10,000 \mathrm{rpm}$ for another five minutes to allow pellet formation. The supernatant was then discarded and the pellet formed was re-suspended in $500 \mu \mathrm{l}$ of sterile distilled water. The suspension was boiled at $100^{\circ} \mathrm{C}$ for ten minutes. Next, the boiled suspension was immediately cooled in ice for five minutes and then centrifuged at $10,000 \mathrm{rpm}$ for ten minutes. The supernatant from the centrifuged suspension was collected and used for PCR amplification [14].

The 16S rRNA gene was amplified with PCR using the universal primers-fD1 (5'-AGAGTTTGATCATGGCTCAG-3') and reverse primer-rP1 (5’-ACGGTTACCTTGTTACGACTT-3'). These are complementary to the 5'-end and 3'-end of prokaryotic 16S rRNA genes. Sequencing of the PCR products was outsourced to Apical Sdn. The nucleotide sequences were analyzed using the BLAST program that compares the nucleotide sequences from the National Center of Biotechnology Information (NCBI) [18] database.

\section{Results and Discussions Morphological determination of isolates}

From the isolation, 35, 15, 37, 39, 24, 26 and 27 pure colonies were isolated from the two rivers in Negeri Sembilan, Melaka, Selangor, Kuala Lumpur, Kedah, Kelantan and Terengganu, respectively (Figure 1). The details on the number of isolates according to the sampling area are tabulated in Table 1. All isolated bacterial colonies were then tested for their susceptibility towards six types of antibiotics, as mentioned previously.

\section{Susceptibility towards antibiotics}

Each isolate was subjected to 2 levels of antibiotic concentration $(10 \mu \mathrm{g} / \mathrm{ml}$ and $30 \mu \mathrm{g} / \mathrm{ml}$, since bacteria's response towards antibiotics is concentration-dependent [19]. Figure 2 shows the percen- tage of ARB isolated from all 14 rivers. Based on Figure 2, most of the isolates possess resistance towards: chloramphenicol (91\%) followed by tetracycline (76\%), ampicillin (74\%), rifampicin (73\%), gentamicin (43\%), and ciprofloxacin (21\%) for antibiotics with the concentration of 30 $\mu \mathrm{g} / \mathrm{ml}$. As for $10 \mu \mathrm{g} / \mathrm{ml}$ of tested antibiotics, $54.68 \%, 53.20 \%, 48.77 \%, 47.78 \%, 46.31 \%$, and $25.62 \%$ of isolates are resistance towards ampicillin, chloramphenicol tetracycline, rifampicin, gentamicin, and ciprofloxacin, respectively. Most isolates are resistant to a higher concentration of antibiotics, especially for chloramphenicol, tetracycline, ampicillin, and rifampicin. Antibiotic resistance or tolerance profile may be developed if the bacteria are exposed to antibiotics at non-lethal concentrations. The antibiotics could exhibit antimicrobial activities on susceptible cells at higher concentration [19].

Figure 3 shows the percentage of ARB isolates grouped according to their respective states. Irrespective of location, most isolates showed higher resistance to a lower concentration of antibiotics. However, there are several instances where isolates showed identical resistance towards antibiotics for example Negeri Sembilan (ciprofloxacin), Melaka (gentamycin, tetracycline and ciprofloxacin), Terengganu (ampicillin and ciprofloxacin). This could reflect the pattern of antibiotics use in each respective state.

Of all tested antibiotics, isolates showed the least resistance towards ciprofloxacin. Isolates from Negeri Sembilan showed no resistance to ciprofloxacin, even at $10 \mu \mathrm{g} / \mathrm{ml}$, which could be due to relatively recent exposure to ciprofloxacin in this particular state. Meanwhile, in Kedah, $65.38 \%$ of isolates showed resistance to ciprofloxacin at $10 \mu \mathrm{g} / \mathrm{ml}$ and $53.85 \%$ at $30 \mu \mathrm{g} / \mathrm{ml}$.

Based on Figure 3, most bacterial isolates from both rivers in Negeri Sembilan showed resistance to gentamicin, ampicillin, chloramphenicol, and tetracycline. Only a few of the isolates showed resistance towards ciprofloxacin. No isolates showed resistance towards ciprofloxacin in both rivers in Negeri Sembilan. Only one isolate showed resistance towards this antibiotic in Melaka River, Melaka, which might be due to the late introduction (1987) of ciprofloxacin in human medication compared to the rest of the tested antibiotics. This might suggest that the bacteria are still developing resistance towards this antibiotic.

The types of antibiotics chosen in this study 


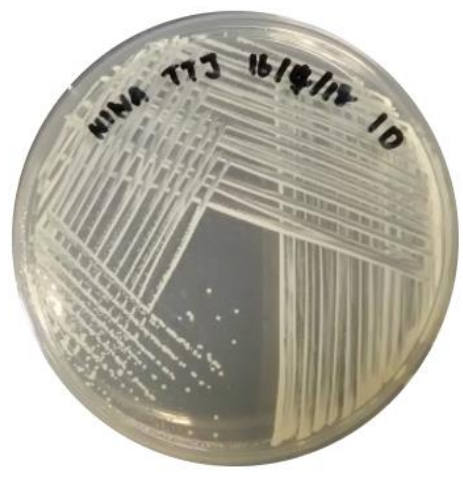

(a)

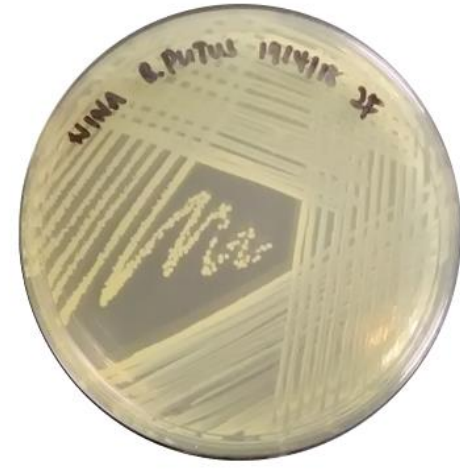

(b)

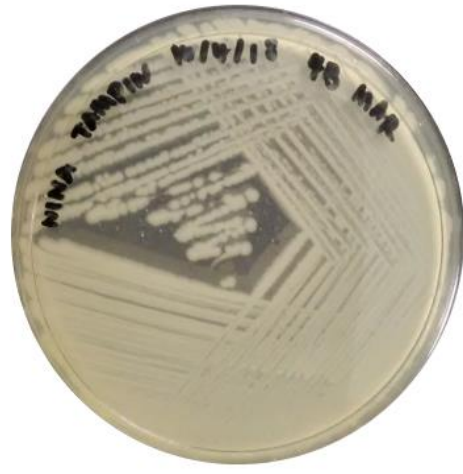

(c)

Figure 1. Pure colonies isolated from the Linggi and Jempol in Negeri Sembilan. (a) Isolate 1D; (b) Isolate 2F; (c) Isolate 4B.

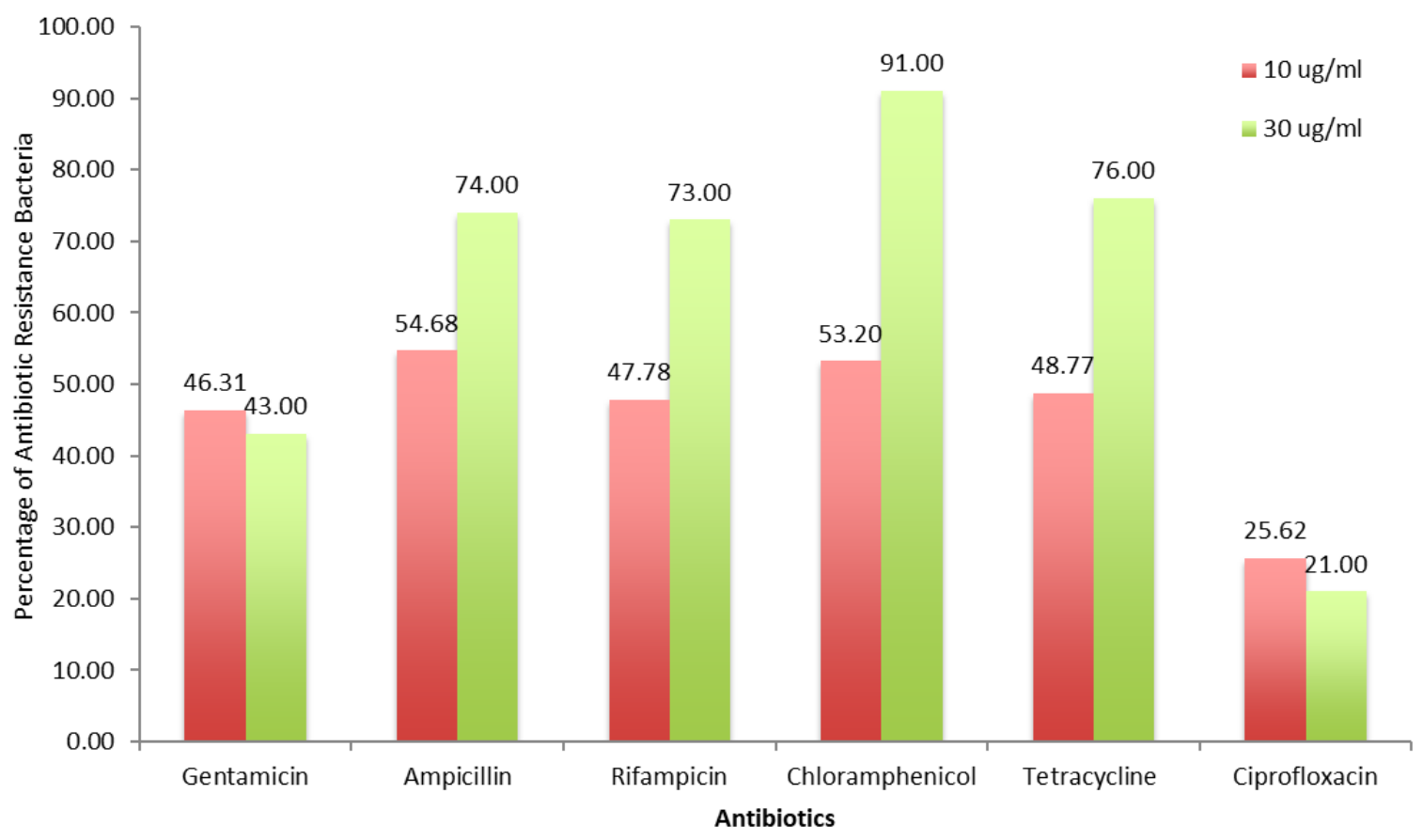

Figure 2. Percentage of isolates resistance towards tested antibiotics

were the most commonly used antibiotics in Malaysia. For example, rifampicin is commonly used to treat several types of bacterial infections, including tuberculosis (TB) and leprosy. Since National TB Control Programme (NTP) in 1961, the case of TB has dropped to below 10 cases [20]. Meanwhile, the launch of National Leprosy Control Centre (NLCC) has reduced leprosy over the years. Due to the relatively small number of TB and leprosy cases, it is expected rifampicin usage would decrease accordingly. Also, the number of resistant strains to rifampicin should be lower than any other strains due to its low usage.

However, from Figure 3, apparently the number isolates that were resistant towards rifampicin is on par with other antibiotics such as gentamicin, chloramphenicol and ampicillin, in which all of these antibiotics were broad-spectrum. This is particularly true for Selangor, Kuala Lumpur and Terengganu. Others district, including Negeri Sembilan, Melaka, Kedah and Kelantan, use rifampicin in a bigger volume to treat TB and leprosy which indicates increase cases of TB and leprosy in Malaysia (for Selangor and Kuala Lumpur). It could be linked to immigrants from countries that have been declared as TB burden countries by WHO such as Bangladesh, Pakistan and Indonesia [21]. With a total of 783,574 people Selangor and Kuala Lumpur contribute to about $44.6 \%$ of total immigrants residing in Malaysia [22]. 


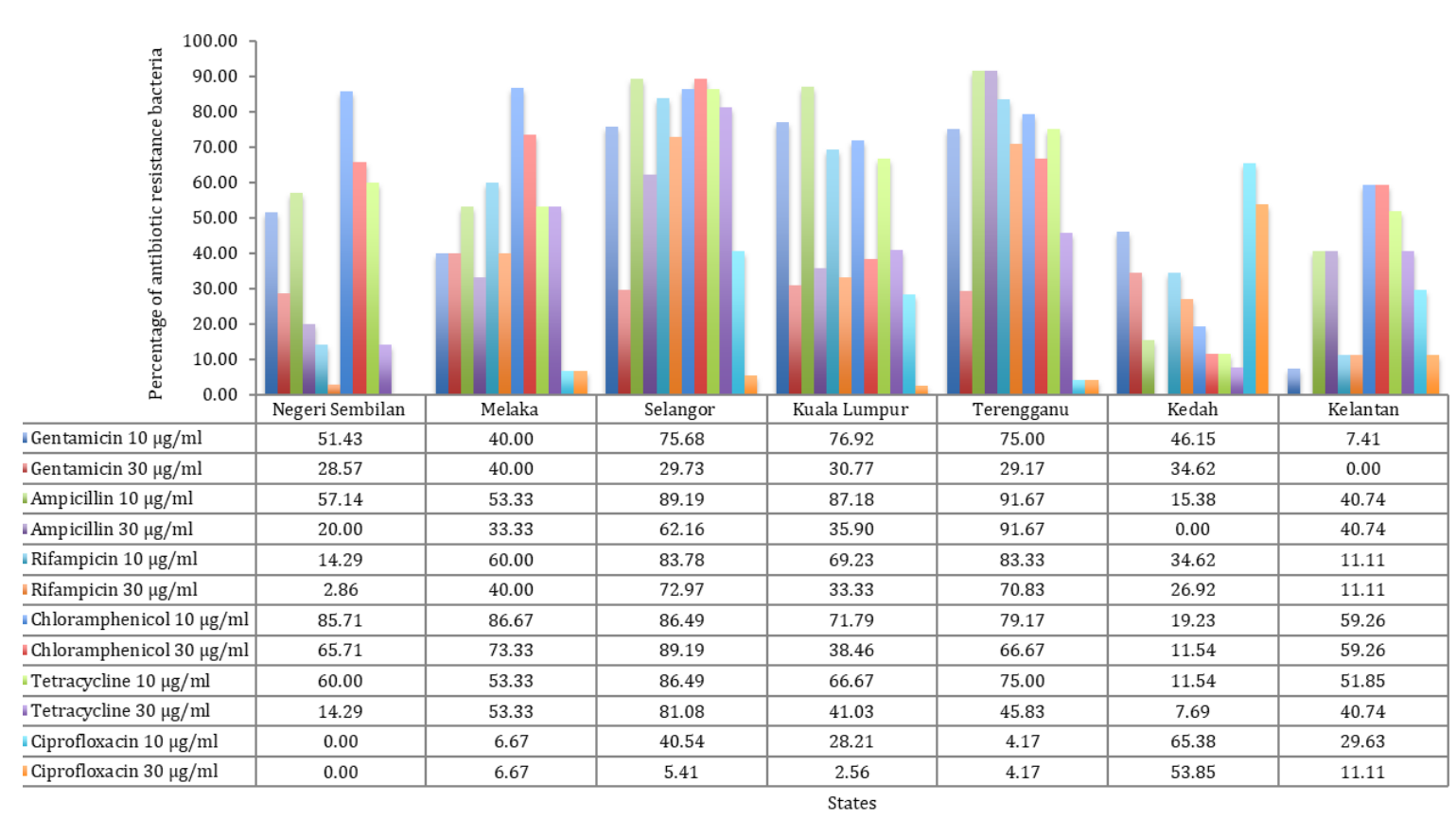

Figure 3. The number of antibiotic resistance bacteria according the sampling area

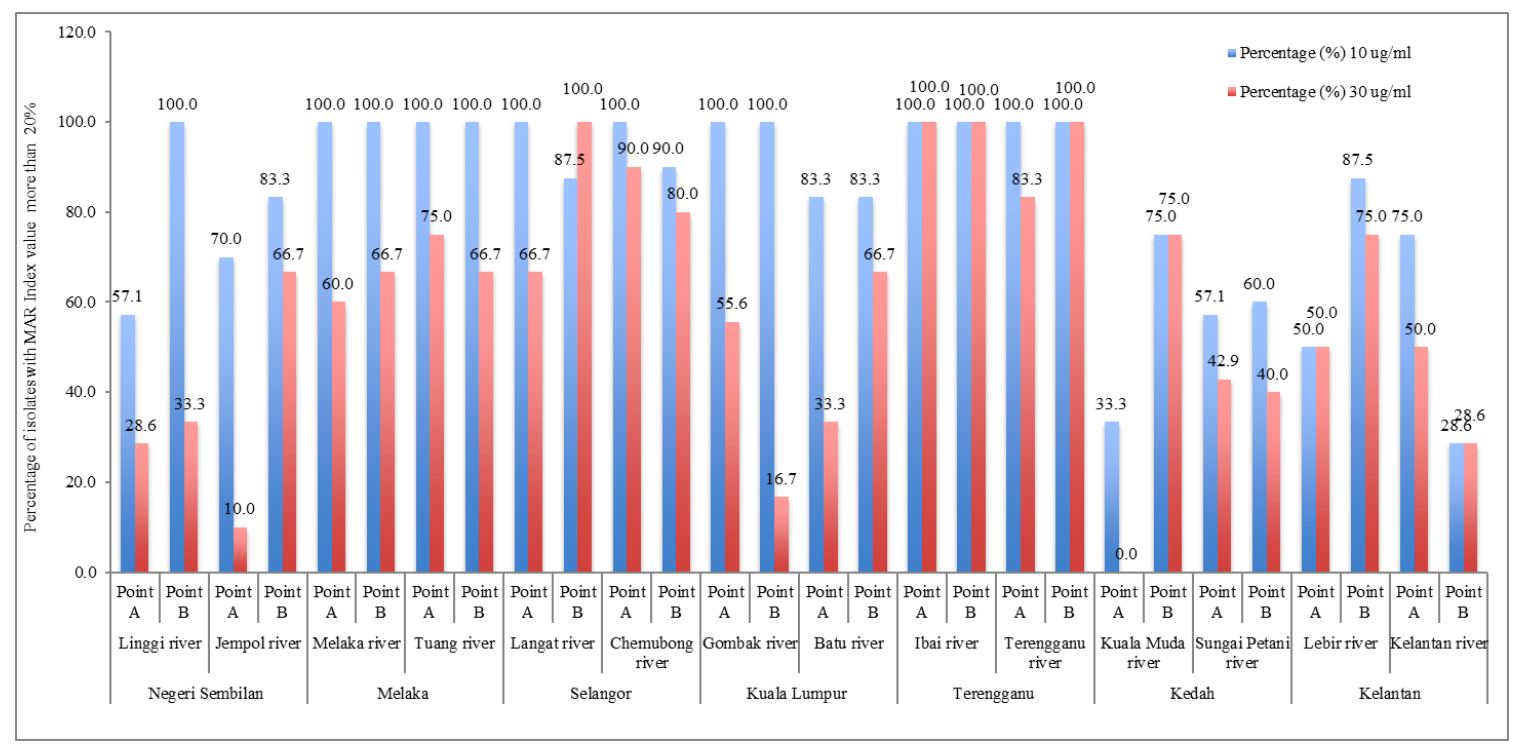

Figure 4. Multiple Antibiotic Resistance (MAR) Index value in sampling area

\section{MAR index value}

Figure 4 shows the MAR index for each sampling point in two different rivers of each state. Bacterial isolates from Terengganu scored the highest MAR value, followed by Kuala Lumpur, Selangor, Kelantan, Negeri Sembilan, Melaka and Kedah. The MAR bacteria were observed to have higher resistance for lower concentration of antibiotics. In Terengganu, the isolates showed the highest resistance towards ampicillin (10 and 30 $\mu \mathrm{g} / \mathrm{ml})$ then it is followed by rifampicin $(10 \mu \mathrm{g} / \mathrm{ml})$ and gentamicin $(10 \mu \mathrm{g} / \mathrm{ml})$. In Kuala Lumpur, the isolates possessed the highest resistance towards ampicillin $(10 \mu \mathrm{g} / \mathrm{ml})$, followed by $10 \mu \mathrm{g} / \mathrm{ml}$ gentamicin and $10 \mu \mathrm{g} / \mathrm{ml}$ chloramphenicol. The trend is quite different in Selangor as the isolates showed resistance towards $10 \mu \mathrm{g} / \mathrm{ml}$ chloramphenicol followed by chloramphenicol $(30 \mu \mathrm{g} / \mathrm{ml})$ and rifampicin $(10 \mu \mathrm{g} / \mathrm{ml})$. In Negeri Sembilan, the highest resistance was towards chloramphenicol $(10 \mu \mathrm{g} / \mathrm{ml})$, followed by chloramphenicol (30 $\mu \mathrm{g} / \mathrm{ml})$ and tetracycline $(10 \mu \mathrm{g} / \mathrm{ml})$. In Melaka, almost similar trends were observed in the highest resistances towards chloramphenicol $(10 \mu \mathrm{g} / \mathrm{ml}$ 
and $30 \mu \mathrm{g} / \mathrm{ml}$ ) that is followed by resistance towards $10 \mu \mathrm{g} / \mathrm{ml}$ of rifampicin.

Based on Figure 4, most bacterial isolates from both rivers in Negeri Sembilan showed resistance to gentamicin, ampicillin, chloramphenicol, and tetracycline. Only a few of the isolates showed resistance towards ciprofloxacin. No isolates showed resistance towards ciprofloxacin in both rivers in Negeri Sembilan, and only one isolate showed resistance towards this antibiotic in Melaka river, Melaka due to the late introduction (in 1987) of ciprofloxacin in human medication compared to the rest of the tested antibiotics. This might suggest that the bacteria are still developing resistance to this antibiotic

Kuala Lumpur and Selangor have scored the highest percentage of ARB, followed by Negeri Sembilan and Melaka. Increased antibiotic resistance was observed for lower concentration of antibiotics. In Kuala Lumpur, the isolates possessed highest resistance towards ampicillin (10 $\mu \mathrm{g} / \mathrm{ml}$ ), followed by $10 \mu \mathrm{g} / \mathrm{ml}$ gentamicin and 10 $\mu \mathrm{g} / \mathrm{ml}$ chloramphenicol. The trend is quite different in Selangor. The isolates showed $10 \mu \mathrm{g} / \mathrm{ml}$ chloramphenicol resistance, followed by chloramphenicol $(30 \mu \mathrm{g} / \mathrm{ml})$ and rifampicin $(10 \mu \mathrm{g} / \mathrm{ml})$. In Negeri Sembilan, the highest resistance was observed in chloramphenicol $(10 \mu \mathrm{g} / \mathrm{ml})$, followed by chloramphenicol $(30 \mu \mathrm{g} / \mathrm{ml})$ and tetracycline $(10 \mu \mathrm{g} / \mathrm{ml})$. In Melaka, almost similar trends were observed as the highest resistances are towards 10 $\mu \mathrm{g} / \mathrm{ml}$ and $30 \mu \mathrm{g} / \mathrm{ml}$ of chloramphenicol. This is followed by resistance towards $10 \mu \mathrm{g} / \mathrm{ml}$ of rifampicin.

At higher concentration, antibiotics exhibited antimicrobial activities on susceptible cells [19]. At lower sub-inhibitory concentrations, the biological response in bacteria will be induced. Bacteria may develop a resistance or tolerance profile if it is exposed to antibiotics at non-lethal concentrations. It could trigger different cellular responses that enable bacteria to defend themselves. Antibiotic-mediated interaction between species may play a substantial role since the microbes are in polymicrobial communities in the natural environment.

Based on the antibiotic susceptibility tests, the MAR index value was calculated for each bacterium to determine the score of each isolate in terms of their ability to resist multiple antibiotics. The MAR index value was calculated using the MAR equation as mentioned previously in the methodology section. MAR refers to bacteria resistance to at least three different antibiotics [17]. A value of the MAR Index value exceeding 20\% represented high risk threats towards the environment [17]. A higher MAR index value is usually observed in areas with a higher accumulation of antibiotics [23, 24].

\section{Identification of the antibiotic resistant bacteria via 16S rRNA gene sequencing}

The rRNA gene was used for identification because it is the most conserved region in all cells, even from distantly related organisms, enabling a more precise sequence alignment for easy comparison between the organisms [25]. For this reason, the 16S rRNA genes have been used extensively for the taxonomy, phylogeny, and the rate of divergence determination among the bacterial species [18].

Table 2 (Supplementary 1) showed the 16s rRNA gene sequencing for the chosen isolates. Isolates 1F, 2A and 2L isolated from Linggi River, Negeri Sembilan were Ralstonia pickettii strain NRBC 102503, Ochrobactrum ciceri strain Ca-34 and Staphylococcus kloosii strain ATCC 43959, respectively. As for Jempol River, Negeri Sembilan, isolates 2A and 2L were recognized as $O$. ciceri strain Ca-34 and Bacillus paramycoides strain MCCC 1A04098. O. ciceri strain Ca-34 isolates Jempol and Linggi River, which showed resistance towards different antibiotics. In addition, isolates with more than 50\% MAR Index value can be found at point 2 (Linggi River) and point 4 (Jempol River).

Results also showed that isolates M5 and M6 from Melaka River, Melaka were identified as Burkholderia vietnamiensis strain TVV75 and Enterobacter xiangfangensis strain 10-17, respectively. As for Tuang River, Melaka isolate T1 - T4 were identified as E. xiangfangensis strain 10-17, Escherichia marmotae strain HT073016, Citrobacter freundii strain ATCC 8090 and Bacillus wiedmannii strain FSL W8-0169, respectively. The common isolates from these rivers also showed resistance towards different antibiotics.

In Langat River, Selangor, isolates LA6, LA7 and LB4 were identified as Staphylococcus hominis subsp. novobiosepticus strain GTC 1228, Vogesella perlucida strain DS-28 and Burkholderia contaminans strain J2956, respectively. Meanwhile, isolates CA4, CA8, CA9, CB5, CB6 
and CB10 were identified as $B$. vietnamiensis strain LMG 10929, B. contaminans strain J2956, B. contaminans strain J2956, Bacillus cereus ATCC 14579, B. vietnamiensis strain LMG 10929 and Pseudomonas otitidis strain MCC10330, respectively. In terms of geographical distribution, B. contaminans strain J2956 was found in both Langat and Chemubong river. The strain isolated from the same point at Chemubong river also showed resistance towards different antibiotics.

As for Gombak river, Kuala Lumpur, isolates $\mathrm{A} 1$, and B1 were identified as P. plecoglossicida strain NBRC 103162. Meanwhile, A3 and B4 were identified as, Acinetobacter baumannii strain DSM 30007 and Pseudomonas plecoglossicida strain NBRC 103162, respectively. Even though A1 and B1 were identified as the same bacteria, these two strains may show resistance towards different antibiotics. Based on this study, A1 and B1 showed resistance towards different types of antibiotics. This is because the same strain was exposed to different antibiotics for a certain period of time as bacteria will develop resistance to counteract the effect of antibiotics that it was exposed. There is also a possibility that the susceptible isolates are still developing resistance towards the other type of antibiotics [26]. Meanwhile, from Batu river, Kuala Lumpur, isolate D6 and D8 both were identified as Acinetobacter baumannii strain DSM 30007 and Ralstonia pickettii strain NBRC 102503.

For Kedah, isolates 2B, 2C and 2D from Kuala Muda river, were identified as Bacillus wiedmannii strain FSL W8-0169, Lysinibacillus fusiformis strain DSM 2898 and Atlantibacter hermanii strain CIP 10376, respectively. Meanwhile, in Sungai Petani, isolate 3D, 4B and 4E were identified as B. cereus ATCC 14579, Achromobacter insuavis strain LMG 26845 and Enterobacter cloacae strain LMG 2683, respectively.

In Kelantan, isolate 2C from Lebir river was identified as Bacillus licheniformis strain DSM 13. Isolates 3G, 3H and 4B isolated from Kelantan river were identified as Microbacterium testaceum strain DSM 20166, Lysinibacillus macroides strain LMG 18474 and B. cereus ATCC 14579, respectively.

In Ibai river, Terengganu, isolates 2A, 2B, 2C and 2I were identified as Chromobacterium violaceum strain ATCC 12472, Enterobacter tabaci strain YIM Hb-3, B. cereus ATCC 14579 and A. baumannii strain DSM 30007, respectively.
Meanwhile in Terengganu river, isolates 3A, 3B, 4A, 4C, 4D and 4E were identified as Klebsiella quasipneumoniae subsp. similipneumoniae strain 07A044, Chromobacterium aquaticum strain CCSEYA-1, Cupriavidus metallidurans strain CH34, Weeksella massiliensis strain FF8, Cupviadus necator strain $\mathrm{N}-1$ and Acinetobacter nosocomialis strain RUH 2376, respectively. Isolate 4A seems to be an important bacterium in antibiotic resistance gene transfer as it is a metal resistance bacterium and the correlation between metal resistance bacteria and antibiotic resistance gene transfer has been proposed [27].

As depicted in Table 2 (Supplementary 1), the isolates comprised pathogenic and non-pathogenic bacteria. A study conducted by von Wintersdorff et al. [28] concluded that many clinically relevant resistance genes could originate from non-pathogenic bacteria. This could happen via horizontal gene transfer (HGT) that causes antibiotic resistance to spread from commensal and environmental species to pathogenic ones. These commensal strains could act as vectors in spreading the ARGs among both the pathogenic and the pathogenic bacteria. Therefore, it is possible that the pathogenic bacteria which originally non-resistant could also develop antibiotic resistance due to prolonged exposure to ARGs and their vectors in a resistome or ARGs reservoir.

\section{Conclusion}

A total of 203 bacteria have been successfully isolated from 14 rivers in 7 different states of Western Peninsular Malaysia (Negeri Sembilan, Melaka, Selangor, Kuala Lumpur, Kedah, Kelantan and Terengganu). About $57.6 \%$ of these isolates showed MAR Index value of more than $20 \%$. Selangor demonstrated the highest percentage of ARB. This suggested that the rivers in Selangor (particularly Chemubong river) are highly contaminated with antibiotics. Based on 16s rRNA gene sequencing, the isolates obtained were from a mixture of pathogenic and commensals bacteria. This also implies that the environment, especially rivers can be a reservoir for genetic jugglery, including the transfer of antibiotic resistance genes.

\section{Acknowledgement}

The authors would like to thank Universiti Teknologi Malaysia for Tier 1 Reseacrh University Grant (GUP) - 17H74 entitled 'Surveillance 
of Antibiotics Resistance Bacteria and Genes in Aquaculture Sources from Johor Streams'.

\section{References}

1. Bisen PS, Raghuvanshi R (2010) Emerging epidemics. 1st Edition. New York, Wiley Blackwell.

2. Jindal BAK, Pandya MK, Khan MID (2015) Antimicrobial resistance: A public health challenge medical. Journal Armed Forces India 71: 178 - 181. doi: 10.1016/j.mjafi.2014.04.011

3. Cole J (2016) Antimicrobial resistance - a 'rising tide' of national (and international) risk. Journal of Hospital Infection 92: 3 - 4. doi.org/10.1016/j.jhin.2015.10.005

4. National Agricultural Statistics Service (2016) Agricultural Statistics. https://www.nass.usda.gov/Publications/Ag_Statistics/index.php. Accessed date: Feb 2020.

5. Palhares, JCP, Kich JD, Bessa MC et al. (2014) Salmonella and antimicrobial resistance in an animal-based agriculture river system. Science of the Total Environment 472: 654 - 661. doi.org/10.1016/j.scitotenv.2013.11. 052

6. García-Feliz C, Collazos JA, Carvajal A et al. (2008) Antimicrobial resistance of Salmonella enterica isolates from apparently healthy and clinically ill finishing pigs in Spain. Zoonoses Public Health 55: 195 - 205. doi: 10.1111/j.1863-2378.2008.01110.x.

7. National Antimicrobial Resistance Monitoring System — enteric bacteria (2007) Food and Drug Administration Executive report. http://www.fda.gov. Accessed date: Feb 2020.

8. Sarmah AK, Meyer MT, Boxall ABA (2006) A global perspective on the use, sales, exposure pathways, occurrence, fate and effects of veterinary antibiotics (VAs) in the environment. Chemosphere 65: 725 - 759. doi: 10.1016/j.chemosphere.2006.03. 026

9. O’neill J, Minghui R, Kuo N et al. (2015) Antimicrobials in Agriculture and the Environment: Reducing Unnecessary Use and Waste. https://amr-review.org/sites/default/files/Antimicrobials\%20in\%20agriculture\%20and\%20the\%20environment\%20-\%20Reducing\%20unnecessary\%20use\%20and\%20waste.pdf. Accessed date: Feb 2020.

10. Witte W (1998) Medical consequences of antibiotic use in agriculture. Science 279: 996 - 997. doi: 10.1126/science.279.5353.9 96

11. Bengtsson-Palme J, Angelin M, Huss M et al. (2015) The human gut microbiome as a transporter of antibiotic resistance genes between continents. Antimicrobial Agents Chemotherapy 59 (10): 6551 - 6560. doi: 10.1128/AAC.00933-15.

12. Zhang X, Li Y, Liu B et al. (2014) Prevalence of Veterinary Antibiotics and Antibiotic-Resistant Escherichia coli in the Surface Water of a Livestock Production Region in Northern China. PLOS One 9 (11): e111026. doi.org/10.1371/journal.pone.011

1026

13. Alhaj N, Mariana NS, Raha AR, Ishak Z (2007) Prevalence of Antibiotic Resistance among Escherichia coli from Different Sources in Malaysia. International Journal of Poultry Science 6 (4): 293 - 297. doi: 10.3923/ijps.2007.293.297
14. Kathleen M, Samuel L, Felecia C et al. (2014). (GTG) 5PCR analysis and 16S rRNA sequencing of bacteria from Sarawak aquaculture environment. In International Food Research Journal, 21 (3): 915 - 920.

15. Department of Statistics Malaysia (2018) Malaysia @ a Glance: Selangor. https://www.dosm.gov.my/v1/index.php?r=col-

umn/cone\&menu_id=eGUyTm9RcEVZSllmYW45dmp nZHh4dz09. Accessed date: Feb 2020.

16. Clinical and Laboratory Standard Institute (2018) Performance Standards for Antimicrobial Susceptibility Testing. 28th Edition. https://clsi.org/media/1930/m100ed28_sample.pdf. Accessed on: Feb 2020.

17. Riaz S, Faisal M, Hasnain S (2011) Antibiotic susceptibility pattern and multiple antibiotic resistances (MAR) calculation of extended spectrum $\beta$-lactamase (ESBL) producing Escherichia coli and Klebsiella species in $\mathrm{Pa}-$ kistan. African Journal of Biotechnology 10 (33): 6325 6331. doi: 10.5897/AJB11.086

18. Clarridge JE (2004) Impact of 16S rRNA Gene Sequence Analysis for Identification of Bacteria on Clinical Microbiology and Infectious Diseases. Clinical Microbiology Reviews 17 (4); 840 - 862. doi: 10.1128/CMR.17.4.840-862.2004

19. Bernier SP, Surette MG (2013) Concentration-dependent activity of antibiotics in natural environments. Front Microbiology 4: 20. doi: 10.3389/fmicb.2013.00020.

20. Iyawoo K (2004) Tuberculosis in Malaysia: problems and prospect of treatmen and control. Tuberculosis (Edinb) 84 (1-2): 4 - 7. doi: 10.1016/j.tube.2003.08.014.

21. World Health Organization (2018) Global Tuberculosis Report. https://www.who.int/tb/publications/global_report/gtbr2018_main_text_28Feb2019.pdf. Accessed date: March 2020.

22. Kementerian Dalam Negeri (2018) Statistik Pekerja Asing Terkini Mengikut Negeri dan Sektor. http://www.data.gov.my/data/ms_MY/dataset/statistikpekerja-asing-terkini-mengikut-negeri-dan-sektor. Accessed date: March 2020.

23. Chitanand M, Kadam T, Gyananath G et al. (2010) Multiple antibiotic resistance indexing of coliforms to identify high risk contamination sites in aquatic environment. Indian Journal of Microbiology 50 (2): 216 - 220. doi: 10.1007/s12088-010-0042-9

24. Osundiya O, Oladele R, Oduyebo O (2013) Multiple antibiotic resistance (MAR) indices of Pseudomonas and Klebsiella species isolates in Lagos University Teaching Hospital. African Journal of Clinical and Experimental $\begin{array}{lllll}\text { Microbiology } & 14 & \text { (3): } 164 & - & 168 .\end{array}$ doi.org/10.4314/ajcem.v14i3.8

25. Woo P, Lau S, Teng J, Tse H, Yuen KY (2008) Then and now: use of $16 \mathrm{~S}$ rDNA gene sequencing for bacterial identification and discovery of novel bacteria in clinical microbiology laboratories. Clinical Microbiology and Infection 14 (10): 908 - 934. doi: 10.1111/j.14690691.2008.02070.x.

26. Davies J, Davies D (2010) Origins and Evolution of Antibiotic Resistance. Microbiology and Molecular Biology Reviews 74 (3): 417 - 433. doi: 10.1128/MMBR.00016-10

27. Mergeay M (2015) The history of Cupriavidus metallidurans strains isolated from anthropogenic environ- 
ments. In: Mergeay M, Van Houdt R, eds. Metal Response in Cupriavidus metallidurans: Volume I: From Habitats to Genes and Proteins. Belgium, Springer. 110.

28. von Wintersdorff CJH, Penders J, van Niekerk JM et al. (2016) Dissemination of antimicrobial resistance in microbial ecosystems through horizontal gene transfer. Frontiers in Microbiology 7: 173. doi: 10.3389/fmicb.2016.00173.

29. Vaz-Moreira I, Tamames J, Martinez JL et al. (2016) Draft Genome Sequences of Two Ralstonia pickettii Strains with Different Aminoglycoside Resistance Phenotypes. Genome Announcements 4 (6): e01257-16. doi: 10.1128/genomeA.01257-16

30. Woods D, Sokol PA (2006) The Genus Burkholderia. The Prokaryotes. 3rd Edition. New York, Springer-Verlag.

31. Harada M (1985) Clinical and Experimental Studies on the Pathogenicity of Clinical Isolated Citrobacter freundii. Hinyokika Kiyo 31 (7): 1159-1170

32. Miller RA, Beno SM, Kent DJ et al. (2016) Bacillus wiedmannii sp. Nov., A Psychrotolerant and Cytotoxic Bacillus cereus Group Species Isolated from Dairy Foods and Dairy Environments. International Journal of Systematic and Evolutionary Microbiology 66 (11): 4744-4753. doi: 10.1099/ijsem.0.001421

33. Ahmed NH, Baruah FK, Grover RK (2017) Staphylococcus hominis subsp. Novobiosepticus, An Emerging Multidrug Resistant Bacterium, as a Causative Agent of Septicaemia in Cancer Patients. Indian Journal of Medical Research 146 (3): 420-425.

34. Nunvar J, Kalferstova L, Bloodworth RAM et al. (2016) Understanding the Pathogenicity of Burkholderia Contaminans, an Emerging Pathogen in Cystic Fibrosis. PLoS ONE 11 (8): e0160975. doi:10.1371/journal.pone.0160975.

35. Kotiranta A, Lounatmaa K, Haapasalo M. (2000) Epidemiology and pathogenesis of $\mathrm{B}$. cereus infections. Microbes Infect 2:189-198.

36. Nishimori E, Kita-Tsukamoto K, Wakabayashi H (2000) Pseudomonas plecoglossicida sp. Nov., the Causative Agent of Bacterial Harmorrhagic Ascites of Ayu, Plecoglossus altivelis. International Journal of Systematic and Evolutionary Microbiology 1 (1): 83-89. doi: 10.1099/00207713-50-1-83.
37. Sieniawski K, Kaczka K, Rucinska M et al. (2013) Acinetobacter bacumannii Nosocomial Infections. Polski Prezeglad Chirurgiczny 85 (9): 483-490. doi: 10.2478/pjs-2013-0075.

38. Sulaiman IM, Hsieh YH, Jacobs E et al. (2018) Identification of Lysinibacillus fusiformis Isolated from Cosmetic Samples Using MALDI-TOF MS and 16S rRNA Sequencing Methods. Journal of AOAC Inernational 101 (6). doi: 10.5740/jaoacint.18-0092.

39. Stenfors Arnesen LP, Fagerlund A, Granum PE (2008) From Soil to Gut: Bacillus cereus and Its Food Poisoning Toxins. FEMS Microbiology Reviews 32 (4): 579-606. doi: 10.1111/j.1574-6976.2008.00112.x.

40. Park MJ, Kim MK, Kim HB et al. (2008) Microbacterium ginsengisolisp. nov., Ab-glucosidase-producing Bacterium Isolated from Soil of a Ginsengfield. International Journal of Systematic and Evolutionary 58: 429433.

41. Park YB, Kim JB, Jin YG, Oh DH (2008) Effect of Temperatures on the Enterotoxin Production of Bacillus cereus in Cereal Grains. Food Science Biotechnology 17: 824-828.

42. Tiwari S, Pattanaik S, Beriha SS (2017) Nonpigmented Strain of Chromobacterium violaceum Causing Neonatal Septicemia: A Rare Case Report. Indian J Pathol Microbiol 60 (3): 427-429. doi: 10.4103/IJPM.IJPM_479_16.

43. Bottone E (2010) Bacillus cereus, A Volatile Human Pathogen. Clin Microbiol Rev 23 (2): 382-398. doi: 10.1128/CMR.00073-09.

44. Rodrigues C, Passet V, Rakotondrasoa A, Brisse S (2018) Identification of Klebsiella pneumoniae, Klebsiella quasipneumoniae, Klebsiella variicola and Related Phylogroups by MALDI-TOF Mass Spectrometry. Frontiers in Microbiology 9: 3000. doi: 10.3389/fmicb.2018.03000.

45. Margeay M, Van Houdt R (2015) Metal Response in Cupriavidus metallidurans. 1st Edition. New York, Springer International Publlishing.

46. Lee YT, Kuo SC, Yang SP et al. (2013) Bacteremic nosocomial pneumonia Caused by Acinetobacter baumannii and Acinetobacter nosocomialis: A Single or Two Distinct Clinical Entities? Clin Microbiol Infect 19 (7): 640645. 


\section{Supplementary 1}

Table 2. Details of 16s rRNA gene sequencing for the chosen isolates

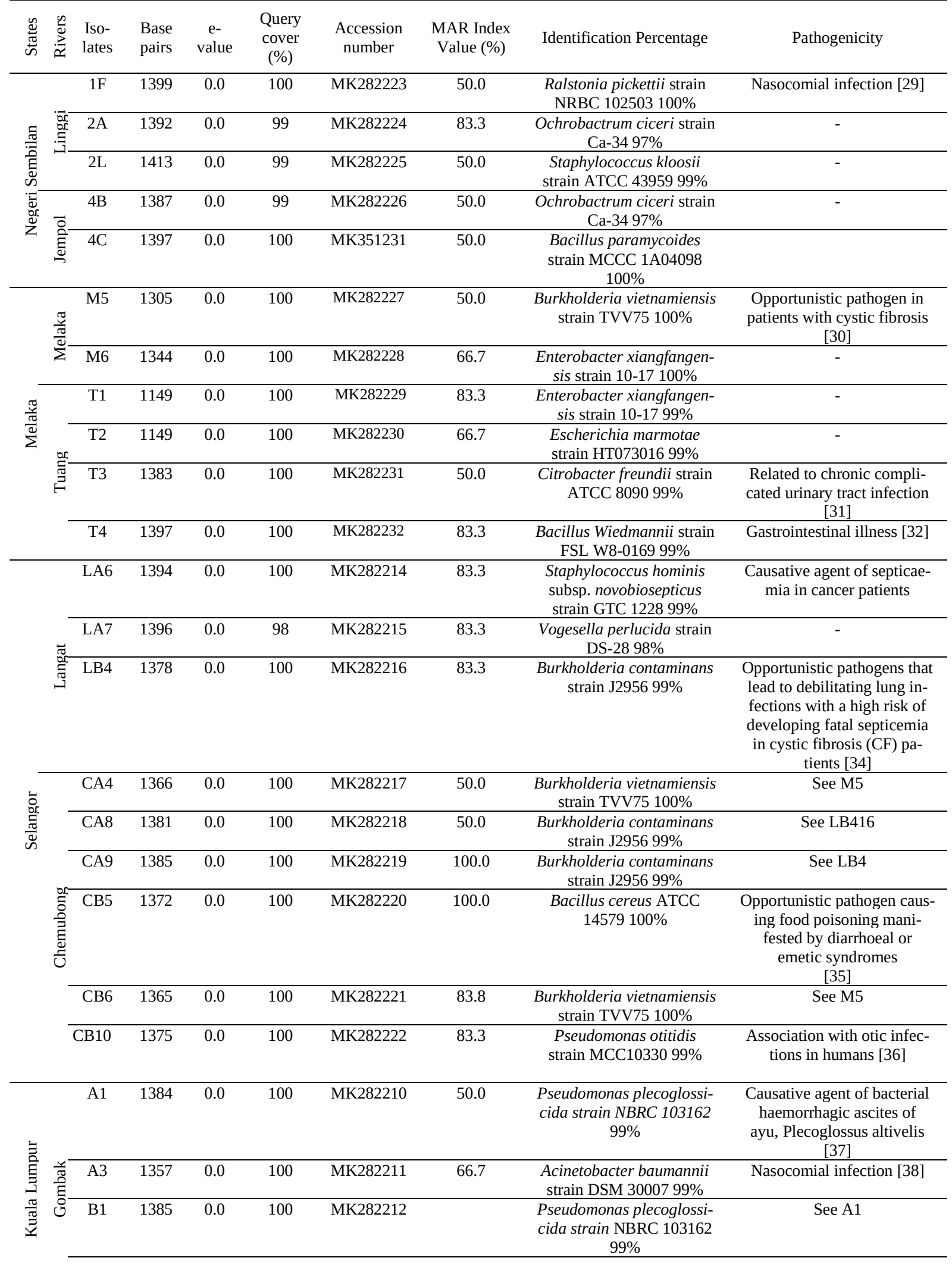

Continue... 
Zain NMZ, Suhaimi MS, Kam KY et al., 2021 / Multi-Drug Resistance Bacteria

\begin{tabular}{|c|c|c|c|c|c|c|c|c|c|}
\hline 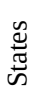 & 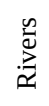 & $\begin{array}{l}\text { Iso- } \\
\text { lates }\end{array}$ & $\begin{array}{l}\text { Base } \\
\text { pairs }\end{array}$ & $\begin{array}{c}\mathrm{e}- \\
\text { value }\end{array}$ & $\begin{array}{l}\text { Query } \\
\text { cover } \\
(\%)\end{array}$ & $\begin{array}{l}\text { Accession } \\
\text { number }\end{array}$ & $\begin{array}{l}\text { MAR Index } \\
\text { Value (\%) }\end{array}$ & Identification Percentage & Pathogenicity \\
\hline & & B4 & 1159 & 0.0 & 100 & MK351228 & 66.7 & $\begin{array}{l}\text { Pseudomonas taiwanensis } \\
\text { strain BCRC } 17751100 \%\end{array}$ & - \\
\hline & & B7 & 1385 & 0.0 & 100 & MK351229 & & $\begin{array}{c}\text { Acinetobacter baumannii } \\
\text { strain DSM } 3000799 \%\end{array}$ & See A3 \\
\hline & $\underset{\pi}{\vec{\pi}}$ & D6 & 1390 & 0.0 & 100 & MK351230 & 83.8 & $\begin{array}{c}\text { Acinetobacter baumannii } \\
\text { strain DSM } 30007 \\
99 \%\end{array}$ & See A3 \\
\hline & & D8 & 1381 & 0.0 & 100 & MK282213 & 50.0 & $\begin{array}{c}\text { Ralstonia pickettii strain } \\
\text { NBRC } 10250399 \%\end{array}$ & See $1 \mathrm{~F}$ \\
\hline \multirow{8}{*}{ ك̃ } & & $2 \mathrm{~B}$ & 1362 & 0.0 & 100 & MN117669 & 33.0 & $\begin{array}{l}\text { Basillus wiedmannii strain } \\
\text { FSL W8-0169 100\% }\end{array}$ & See T4 \\
\hline & 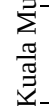 & $2 \mathrm{C}$ & 2525 & 0.0 & 99 & MN598655 & 33.0 & $\begin{array}{c}\text { Lysinibacillus fusiformis } \\
\text { strain DSM } 2898 \\
98.59 \% \\
\end{array}$ & $\begin{array}{c}\text { Tropical ulcers, severe sep- } \\
\text { sis, and respiratory illnesses } \\
{[39]} \\
\end{array}$ \\
\hline & & $2 \mathrm{D}$ & 1388 & 0.0 & 100 & MN117670 & 50 & $\begin{array}{l}\text { Atlantibacter hermanii } \\
\text { strain CIP } 10376100 \%\end{array}$ & - \\
\hline & \multirow{5}{*}{ 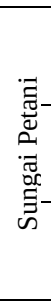 } & & 1367 & 0.0 & 100 & MN117671 & 33 & $\begin{array}{c}\text { Bacillus cereus ATCC } \\
1457999.7 \%\end{array}$ & Diarrhoel disease [40] \\
\hline & & $3 \mathrm{D}$ & & & & & & & \\
\hline & & $4 \mathrm{~B}$ & 1319 & 0.0 & 100 & MN117672 & 33 & $\begin{array}{c}\text { Achromobacter insuavis } \\
\text { strain LMG } 2684597.19 \%\end{array}$ & - \\
\hline & & & 1349 & 0.0 & 99 & MN117673 & 33 & $\begin{array}{c}\text { Enterobacter cloacae } \\
\text { strain LMG } 268399.85 \%\end{array}$ & - \\
\hline & & $4 \mathrm{E}$ & & & & & & & \\
\hline \multirow{4}{*}{ 胥 } & : & $2 \mathrm{C}$ & 1430 & 0.0 & 100 & MN117660 & & $\begin{array}{l}\text { Bacillus licheniformis } \\
\text { strain DSM } 1392.73 \%\end{array}$ & See $1 \mathrm{D}$ \\
\hline & \multirow{3}{*}{ 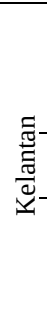 } & $3 G$ & 1402 & 0.0 & 99 & MN117661 & 50.0 & $\begin{array}{l}\text { Microbacterium testaceum } \\
\text { strain DSM } 2016697.08 \%\end{array}$ & $\begin{array}{c}\text { Food poisioning, gastroenter- } \\
\text { itis, meningitis, septicemia, } \\
\text { gingival and ocular infection } \\
\text { [41] }\end{array}$ \\
\hline & & $3 \mathrm{H}$ & 1436 & 0.0 & 98 & MN117662 & 50.0 & $\begin{array}{l}\text { Lysinibacillus macroides } \\
\text { strain LMG } 1847496.6 \%\end{array}$ & - \\
\hline & & $4 \mathrm{~B}$ & 1438 & 0.0 & 99 & MN117663 & 50.0 & $\begin{array}{c}\text { Bacillus cereus ATCC } \\
1457996.59 \%\end{array}$ & $\begin{array}{c}\text { Food poisioning, gastroenter- } \\
\text { itis, meningitis, septicemia, } \\
\text { gingival and ocular infection } \\
\text { [41] }\end{array}$ \\
\hline \multirow{8}{*}{ 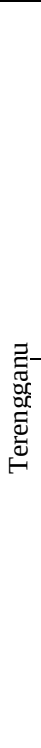 } & \multirow{8}{*}{ 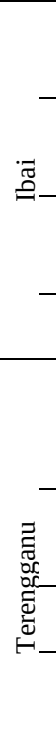 } & $2 \mathrm{~A}$ & 1301 & 0.0 & 100 & MN117664 & 33.0 & $\begin{array}{c}\text { Chromobacterium vio- } \\
\text { laceum strain ATCC } 12472 \\
99.2 \% \\
\end{array}$ & $\begin{array}{c}\text { Neonatal septicemia infec- } \\
\text { tion [42] }\end{array}$ \\
\hline & & $2 \mathrm{~B}$ & 1799 & 0.0 & 99 & MN598656 & 67.0 & $\begin{array}{c}\text { Enterobacter tabaci strain } \\
\text { YIM } \mathrm{Hb}-3 \\
96.59 \%\end{array}$ & - \\
\hline & & $2 \mathrm{C}$ & 2623 & 0.0 & 99 & MN598657 & 33.0 & $\begin{array}{c}\text { Bacillus cereus ATCC } \\
14579 \\
99.72 \%\end{array}$ & Food poisoning [43] \\
\hline & & 2I & 1290 & 0.0 & 100 & MN117674 & 33.0 & $\begin{array}{l}\text { Acinetobacter baumannii } \\
\text { strain DSM } 30007 \text { 100\% }\end{array}$ & See A3 \\
\hline & & $3 \mathrm{~A}$ & 2519 & 0.0 & 100 & MN598658 & 67.0 & $\begin{array}{c}\text { Klebsiella quasipneu- } \\
\text { moniae subsp. similipneu- } \\
\text { moniae strain 07A044 } \\
99.42 \% \\
\end{array}$ & $\begin{array}{c}\text { Human and animal infection } \\
{[44]}\end{array}$ \\
\hline & & 3B & 1303 & 0.0 & 100 & MN117665 & 50.0 & $\begin{array}{c}\text { Chromobacterium aquat- } \\
\text { icum strain CC-SEYA-1 } \\
100 \% \\
\end{array}$ & - \\
\hline & & $4 \mathrm{~A}$ & 1297 & 0.0 & 100 & MN117666 & 50.0 & $\begin{array}{c}\text { Cupriavidus metallidurans } \\
\text { strain CH34 100\% }\end{array}$ & $\begin{array}{c}\text { Metal-resistance bacterium } \\
{[45]}\end{array}$ \\
\hline & & $4 \mathrm{C}$ & 2501 & 0.0 & 100 & MN598659 & 33.0 & $\begin{array}{c}\text { Weeksella massiliensis } \\
\text { strain FF8 } \\
99.93 \% \\
\end{array}$ & - \\
\hline
\end{tabular}

Continue... 
Zain NMZ, Suhaimi MS, Kam KY et al. et al., 2021 / Multi-Drug Resistance Bacteria

\begin{tabular}{|c|c|c|c|c|c|c|c|c|c|}
\hline$\frac{\mathscr{0}}{\tilde{\pi}}$ & 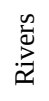 & $\begin{array}{l}\text { Iso- } \\
\text { lates }\end{array}$ & $\begin{array}{l}\text { Base } \\
\text { pairs }\end{array}$ & $\begin{array}{c}\text { e- } \\
\text { value }\end{array}$ & $\begin{array}{l}\text { Query } \\
\text { cover } \\
(\%)\end{array}$ & $\begin{array}{l}\text { Accession } \\
\text { number }\end{array}$ & $\begin{array}{c}\text { MAR Index } \\
\text { Value (\%) }\end{array}$ & Identification Percentage & Pathogenicity \\
\hline & & $4 \mathrm{D}$ & 1318 & 0.0 & 100 & MN117667 & 67.0 & $\begin{array}{l}\text { Cupviadus necator strain } \\
\qquad N-1100 \%\end{array}$ & - \\
\hline & & $4 \mathrm{E}$ & 1313 & 0.0 & 100 & MN117668 & 67.0 & $\begin{array}{c}\text { Acinetobacter nosocomi- } \\
\text { alis strain RUH } 2376 \\
100 \%\end{array}$ & Nasocomial pnuemonia [46] \\
\hline
\end{tabular}


This page is intentionally left blank. 